\title{
Main Factors Involved in Thyroid Hormone Action
}

\author{
Lorena Tedeschi $^{1}\left(\mathbb{D}\right.$, Cristina Vassalle ${ }^{2}\left(\mathbb{D}\right.$, Giorgio Iervasi ${ }^{1}$ and Laura Sabatino ${ }^{1, *(D)}$ \\ 1 Institute of Clinical Physiology, CNR, 56127 Pisa, Italy; lorena.tedeschi@ifc.cnr.it (L.T.); iervasi@ifc.cnr.it (G.I.) \\ 2 Fondazione CNR-Regione Toscana Gabriele Monasterio, 56127 Pisa, Italy; cristina.vassalle@ftgm.it \\ * Correspondence: laura.sabatino@ifc.cnr.it
}

check for

updates

Citation: Tedeschi, L.; Vassalle, C.; Iervasi, G.; Sabatino, L. Main Factors Involved in Thyroid Hormone Action. Molecules 2021, 26, 7337. https:// doi.org/10.3390/molecules26237337

Academic Editor: Raffaele Capasso

Received: 2 November 2021

Accepted: 1 December 2021

Published: 3 December 2021

Publisher's Note: MDPI stays neutral with regard to jurisdictional claims in published maps and institutional affiliations.

Copyright: (c) 2021 by the authors. Licensee MDPI, Basel, Switzerland. This article is an open access article distributed under the terms and conditions of the Creative Commons Attribution (CC BY) license (https:// creativecommons.org/licenses/by/ $4.0 /)$.

\begin{abstract}
The thyroid hormone receptors are the mediators of a multitude of actions by the thyroid hormones in cells. Most thyroid hormone activities require interaction with nuclear receptors to bind DNA and regulate the expression of target genes. In addition to genomic regulation, thyroid hormones function via activation of specific cytosolic pathways, bypassing interaction with nuclear DNA. In the present work, we reviewed the most recent literature on the characteristics and roles of different factors involved in thyroid hormone function in particular, we discuss the genomic activity of thyroid hormone receptors in the nucleus and the functions of different thyroid hormone receptor isoforms in the cytosol. Furthermore, we describe the integrin $\alpha \mathrm{v} \beta 3$-mediated thyroid hormone signaling pathway and its rapid nongenomic action in the cell. We furthermore reviewed the thyroid hormone transporters enabling the uptake of thyroid hormones in the cell, and we also include a paragraph on the proteins that mediate thyroid receptors' shuttling from the nucleus to the cytosol.
\end{abstract}

Keywords: thyroid hormones; thyroid hormone receptor; integrin; genomic; nongenomic

\section{Introduction}

Thyroid hormones (THs) are important regulatory molecules in the human body that mediate many metabolic and developmental processes (e.g., increased basal metabolic rate, lipolysis/lipogenesis, adaptive thermogenesis, etc.) [1-4]. The principal hormone secreted by the thyroid gland and released into the blood stream is thyroxine (T4). The major metabolite, triiodothyronine (T3), is considered to be the biologically active form of $\mathrm{THs}$ and is derived from outer ring deiodination of $\mathrm{T} 4$ at peripheral tissue sites by specific enzymes called deiodinases [5]. The action of THs requires several milestones, the best known of which is TH binding to specific nuclear receptors and interaction with target DNA. Furthermore, THs may also act through alternative pathways devoid of interaction with nuclear receptors, leading to a more rapid $\mathrm{TH}$ action after binding to plasma membrane or cytoplasmic sites. TH action is generally defined as genomic when it directly involves interaction of the hormone with the nuclear receptor, and nongenomic when TH action is not initiated by interaction with specific nuclear receptors. However, the latter distinction has recently been found to be overly simplistic and misleading since it seems to suggest that the nongenomic pathways lack involvement in the regulation of gene expression [6]. Instead, gene modulation may often occur consequently to nongenomic pathway activation. The aim of this review is to discuss the principal factors regulating TH effects in the cell both at the nuclear level, where a direct interaction of thyroid hormone receptors (TRs) and the DNA target occurs, and in the cytosol, where TR isoforms are involved, at least in part, in rapid nongenomic responses. Furthermore, the integrin $\alpha \mathrm{v} \beta 3$-mediated effects of TH on specific metabolic pathways are also discussed.

\section{TH Transporters}

Having reached their target tissues, THs enter the cells through specific cell membrane transporters [7] (Table 1). Among the so-called monocarboxylate transporter family, MCT8 is considered very specific for THs, showing the highest affinity for T3 and less for T4. 
MCT8 was found to transport also inactive metabolites such as reverse T3 (rT3) and 3,3'T2 [8]. It is notable that mutations in the gene for MCT8 (SLC16A2) result in impairment of TH passage through the blood-brain barrier and are associated with severe neurological diseases (i.e., Allan-Herndon-Dudley syndrome) [9]. Interestingly, Mct8-deficient mice present only endocrine dysfunctions and do not seem to have the neurological manifestations observed in humans, which may be due to the recruitment of secondary TH transporters [10]. MCT8 is considered the "primary" TH transporter since it is specific for THs, whereas the "secondary" transporters also mediate the uptake of compounds other than THs, such as MCT10, which belongs to the same family as MCT8 and is also an aromatic amino acid transporter. Other secondary transporters include the organic anion transporter polypeptides (such as OATP1C1, OATP1A2, OATP1A4), which mediate the transport of bile acids and steroid hormones, and the large neutral amino acid transporters (such as LAT1 and LAT2), which mediate the entrance of phenylalanine, tyrosine, leucine, arginine, and tryptophan into cells [7].

\section{Thyroid Hormone Receptors and Nuclear Functions}

\subsection{General Characteristics of Thyroid Hormone Receptors}

The biological activities of $\mathrm{T} 3$ via transcriptional regulation are mediated by thyroid hormone receptors (TRs) which are encoded by two different genes, called THRA and $T H R B$, and in humans are located on chromosomes 17 and 3, respectively [11]. The two genes generate different variants via alternative splicing: THRA's main products are TR $\alpha 1$, $\mathrm{TR} \alpha 2$, and TR $\alpha 3$, whereas THRB's main products are TR $\beta 1$, TR $\beta 2$, and, described only in rats, TR $\beta 3$ (Table 1 ).

Table 1. Main factors mediating TH action.

\begin{tabular}{|c|c|c|c|c|}
\hline & Cellular Localization & Ligand & Factor & $\begin{array}{c}\text { DNA } \\
\text { Interaction }\end{array}$ \\
\hline $\begin{array}{l}\text { Nuclear } \\
\text { receptors }\end{array}$ & Nucleus & T3 & $\mathrm{TRa}, \mathrm{TRb}$ & TREs \\
\hline $\begin{array}{l}\text { Extra-nuclear } \\
\text { receptors }\end{array}$ & Cytoplasm/Mitochondria & T3 & $\begin{array}{c}\text { TRa1 (p46) } \\
\text { p43/p33/p30/p38 }\end{array}$ & mit-TREs \\
\hline Integrin & Cell membrane & $\mathrm{T} 4 / \mathrm{T} 3$ & Integrin avb3 & Absent \\
\hline
\end{tabular}

The THRA locus contains 10 exons and the spicing site for the TR $\alpha 2$ variant is in exon 9. The THRB locus contains 11 exons, among which only exons 3 to 8 are in common to all the TR $\beta$ isoforms and present a high homology with TR $\alpha$ isoforms [12]. Direct interaction of T3 with target genes is mediated by nuclear thyroid hormone receptors (TRs), which bind to specific sequences called thyroid response elements (TREs). TREs are located in the regulatory regions of target genes, acting as enhancers (positive TREs) or silencers (negative TREs) of transcription [13] (Figure 1). TREs are formed either by a palindrome hexamer (AGGTCA) called "half-site" or by direct repeats of this sequence, spaced by four nucleotides [14]. TRs belong to a family of nuclear receptors which bind DNA as dimers-more specifically, as homodimers or heterodimers with 9-cis-retinoic acid receptors (RXR)s [15], liver $X$ receptor [16], and PPARs [17].

A peculiar aspect of TR is that its regulatory action on positive TREs as a repressor does not require binding to the ligand. Instead, the presence of co-factors (specifically called co-repressors) is needed to silent the target gene. Upon T3 interaction with TR, the co-repressor is released and the following conformational change allows TR to interact with a co-activator, allowing target gene transcription [18] (Figure 1). 


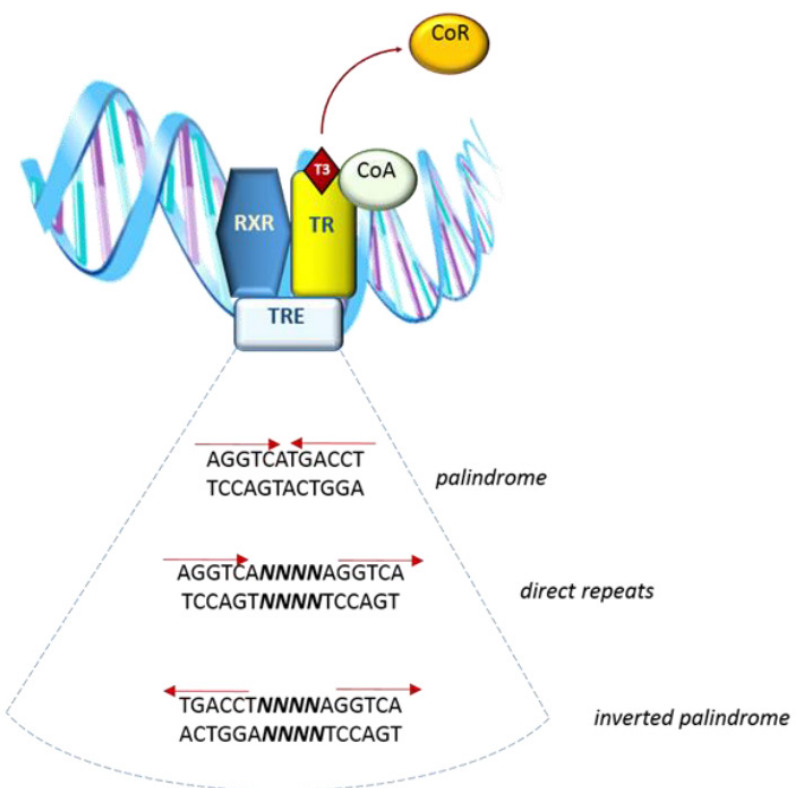

Figure 1. Simplified representation of interaction of the complex T3-TR dimer-CoActivator and TRE sequence in the target gene.

\subsection{TRs' Multidomain Structure}

All TRs have a multidomain structure: (1) the A/B domain includes the variable $\mathrm{N}$-terminal region, which is not present in the truncated forms of TRs and is believed to be involved in the interaction with co-factors; (2) the C domain (DNA Binding Domain; DBD) with two zinc fingers, containing specific motifs to recognize DNA ("P-box") and to distinguish the spacing between half-sites in TREs ("D-box"); (3) the linker D domain, which contains an unfolded hinge to facilitate the rotation between the ligand binding domain (LBD) and DBD; and (4) the E/F domain, with LBD, which displays the interface for homo- or hetero-dimerization. In particular, the $\mathrm{E} / \mathrm{F}$ domain drives all the conformational changes after ligand binding and interaction with co-regulators. In detail, in the inactive form, LBD binds the co-repressors, which maintain target gene silence; upon T3 binding, helix 12 (in the final part of the protein) relocates to a different position, releasing the corepressor and displaying a new surface for co-activator recruitment. Co-activators mediate chromatin remodeling (i.e., by histone acetylation or methylation) and the interactions among RNA polymerase and other transcriptional factors [19]. Finally, LBD contains a hydrophobic surface (with heptad repeats) for dimerization [20,21]. TR $\alpha 2$ and $\operatorname{TR} \alpha 3$ have an incomplete LBD domain and, although the exact roles of these isoforms are not completely clear, since their dimerization with the full-length receptors is still possible, they probably function only as constitutive repressors of TR-mediated transcription [11,22] (Figure 2).
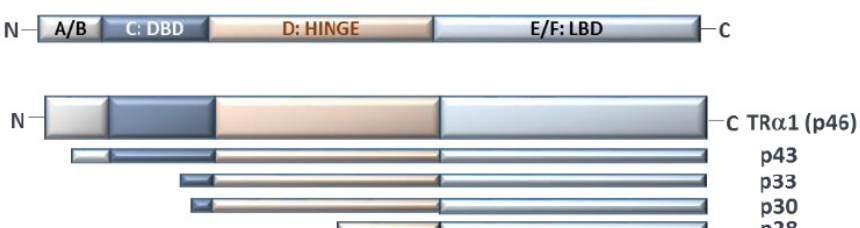

$$
\mathrm{N}
$$

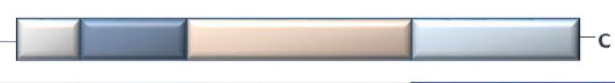

TR $\alpha 2$

$\mathrm{N}-$

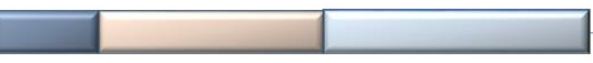

C TR $\beta 1$

$\mathrm{N}-$

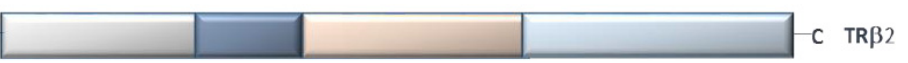

Figure 2. Schematic representation of the main TH isoforms. A/B: N-terminal domain, C: DNA binding domain (DBD), D: hinge region, E/F: ligand binding domain (LBD). 


\subsection{TR Tissue Distribution}

TR isoforms found in human, rat, and mouse tissues have highly homologous amino acid sequences [18]. This conservation among species depends on the fact that there are important specialized functions for each isoform in different organs, and TR isoforms are selectively distributed on the basis of their roles and developmental stage [23].

$\mathrm{TR} \alpha 1, \mathrm{TR} \alpha 2$, and TR $\beta 1$ are expressed at different relative levels in different tissues, even though TR $\alpha 1$ and TR $\alpha 2$ receptors are mainly present in the central nervous system and muscle, and TR $\Delta \alpha$ isoforms in the intestine; TR $\beta 1$ is the principal isoform in the liver, $\operatorname{TR} \beta 2$ in the hypothalamus, pituitary, and retina, and TR $\beta 3$ and TR $\Delta \beta 3$ are limited to the liver, spleen, heart, and lungs [24-27]. It is noteworthy that in the liver, all the isoforms $\alpha$ and $\beta$ show a zonal distribution, suggesting that there might be different sets of genes more specifically activated by one or more isoforms, depending on their location in the organ [28].

Interestingly, there is only a single amino acid difference between the LBDs of the $\operatorname{TR} \alpha$ and TR $\beta$ receptors, which is a very important issue in the development of TR-isoformselective analogues for therapeutic purposes $[29,30]$

Moreover, it has been observed that in several tissues, a critical TR mass, rather than the presence of a particular variant, may be relevant for TH action. Nevertheless, in other conditions, the type of TR isoform may be a more specific determinant. Thus, the fine balancing of the total TR mass and relative composition of TR types, according to the needs of the cell, may explain, at least in part, the diverse range of TH actions in different tissues [31].

\subsection{TR Nucleus-Cytoplasm Shuttling}

The nuclear envelope acts like a selectively permeable barrier. Regardless of direction, the passage requires the presence of the nuclear pore complex (NPC), which acts as regulatory gatekeeper [32]. Nuclear import of small molecules (less than $40 \mathrm{kDa}$ ) can occur by passive diffusion through the central channel of the NPCs, whereas import of larger proteins requires an energy-dependent process mediated by specific signal motifs called nuclear localization signals (NLS). The main TR actions occur within the nucleus via interaction with specific target genes responsive to THs. However, TRs can shuttle back to the cytoplasm, crossing the nuclear envelope and being involved in several cellular processes. More specifically, in vitro studies of cell models have shown that the nuclear import of TR $\alpha 1$ involves soluble factors in the cytosol called importin 7 , importin $\beta 1$, and adapter importin $\alpha 1$. This active transport is abolished by exposure to low temperatures [33]. Importins bind TRs at lysine- and arginine-rich nuclear localization signal (NLS1 and NLS2) motifs, localized in the hinge and A/B domains respectively [25]. It is noteworthy that TR $\beta 1$, which has no NLS- 2 motif, is more abundant than TR $\alpha 1$ in the cytosol. TR transfer from nucleus to cytoplasm is mediated by several exportins and nuclear export signal (NES) motifs in the LBD domain. Exportins include CRM1 (chromosome maintenance factor 1, also known as exportin 1), which cooperates with calreticulin, and exportins 4, 5, 6, and 7 [34]. In vitro studies have shown that overexpression of exportins 5 and 7 leads to a major distribution of TRs in the cytosolic compartment. However, when TR $\beta 1$ and exportins 4, 5, or 7 were co-expressed, no variation in T3-mediated gene expression was observed. In contrast, when the unliganded TR $\alpha 1$ was co-expressed with exportin 7, it was less efficient in repressing target gene transcription [34].

The balance between nuclear import and export of TRs is considered a crucial checkpoint for regulation of TH-dependent gene expression, and it is believed that post-translational modifications at several amino acid side chains such as cysteine, serine, threonine, tyrosine, and, above all, lysine (targeted by acetylation, ubiquitylation, sumoylation, methylation) may contribute to the efficacy of these processes [35]. In particular, TR $\alpha$ is a target for acetylation by cAMP-response element-binding acetyltransferase (CBP). This post-translational modification, which occurs at the DBD domain (in Lys residues: K128/K132/K134), ameliorates efficiency of receptor binding to DNA; in fact, substitution of Lys with Arg residues 
decreases DNA-binding strength and seriously interferes with T3-dependent activation of target genes [36].

\subsection{TR Extranuclear Functions}

Beside the well-studied functions at the nuclear level, a few emerging roles of TRs in the cytoplasm compartment have been investigated. For example, in normal conditions, several truncated isoforms of TR $\alpha$ have been described at the inner surfaces of the plasma membrane and mitochondria, suggesting their involvement in functions outside the cell nucleus [37]. In particular, the p28 truncated TR $\alpha 1$ isoform, with N-terminal deletion of A/B domain, is located at the mitochondrial inner membrane. Even though the role of p28 has yet to be completely clarified, given its co-localization with adenine nucleotide translocase (ANT) and uncoupling proteins (UCPs), it has been proposed to be involved in the early mitochondrial response to T3 [38]. Another known TR $\alpha 1$ mitochondrial isoform is $\mathrm{p} 43$, which binds to T3 with a similar affinity with respect to TR $\alpha 1$ and acts as a potent T3-dependent transcription factor of the mitochondrial genome, mediating the interaction with specific mit-TREs and thus regulating mitochondrial gene expression [39] (Table 1, Figure 2).

\section{Integrin $\alpha v \beta 3$ Mediation of TH Action}

In several conditions, $\mathrm{TH}$ effects can be observed within minutes, a very short period for a response requiring transcriptional regulation and, in most cases, T4 is more effective than T3. These signals, independent of ligand binding to nuclear TRs, are mediated at the plasma membrane by protein integrin $\alpha \mathrm{v} \beta 3$ (Table 1). Integrin $\alpha \mathrm{v} \beta 3$ is a member of the integrin family, which consists of cell adhesion receptors that play important roles during developmental and pathological processes. The integrin family includes $24 \alpha \beta$ heterodimeric members mediating the attachment of cells to the extracellular matrix (ECM) and involved in specialized cell-cell interactions. Integrin $\alpha v \beta 3$ is one of a subset of integrins (8 out of 24); it recognizes the RGD (Arg-Gly-Asp) sequence in the native ligands and has been shown to have a panel of small molecule ligands [40]. Integrin $\alpha v \beta 3$ contains a TH-binding domain which binds T4 and, with lower affinity, T3, thus activating PI3K/AKT and MAPK (ERK1/2) downstream pathways [41] (Figure 3).

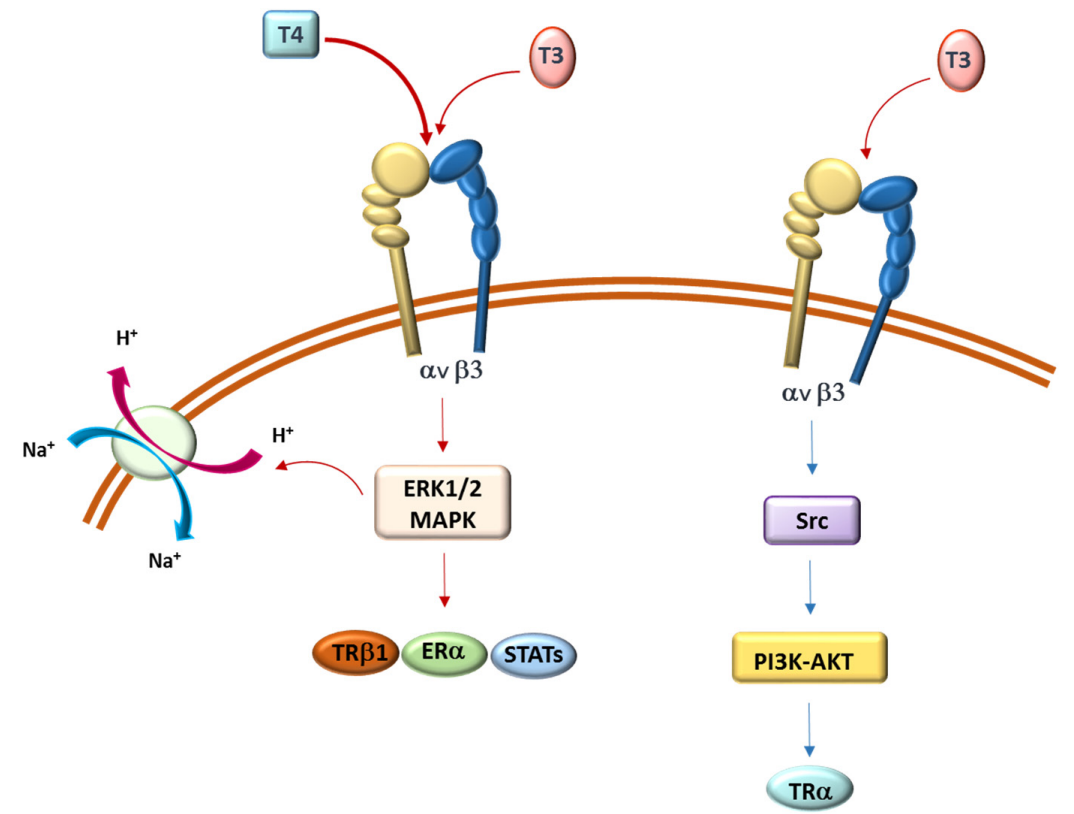

Figure 3. Representation of plasma membrane integrin $\alpha \mathrm{v} \beta 3$, its interaction with THs (T3 and T4), main cell signaling activated MAPK (ERK1/2) and PI3K-AKT, and main target proteins identified to date (TR $\beta 1, \mathrm{ER} \alpha$, STATs, $\mathrm{Na}^{+} / \mathrm{H}^{+}$antiporter, and TR $\left.\alpha 1\right)$ [41-45]. 
At physiological concentrations, $\mathrm{T} 4$ is the main ligand for integrin $\alpha \mathrm{v} \beta 3$ and data obtained with radiolabeled T4 experiments showed that tetraiodothyroacetic acid (tetrac), integrin $\alpha v \beta 3$ antibodies, and integrin RGD recognition-site peptide [46] could displace this binding. A study by Cao et al. on CV-1 cells showed that the translocation activity of TR $\beta 1$ from the cytoplasm to the nucleus is initiated by T4 at the plasma membrane through the mediation of integrin $\alpha \mathrm{v} \beta 3$ [42]. In fact, CV-1 cells, which lack nuclear TRs but express plasma membrane integrin $\alpha v \beta 3$, once treated with physiological concentrations of T4, show an activation of MAPK pathway which is inhibited by the silencing of integrin $\alpha \mathrm{v} \beta 3$ [41].

Furthermore, the finding that the occlusion by an antagonist of RGD site of integrin $\alpha v \beta 3$ leads to blockage of T4 activity suggests that T4-integrin $\alpha v \beta 3$ interaction occurs at or near the RGD site [47]. Molecular modeling studies have demonstrated that the THs and their analogues occupy a much smaller conformational space than does the RGD cyclic peptide (which is the model ligand for RGD binding integrin investigation), suggesting that there can be different possible orientations of THs and analogues in the binding site at the interface between the $\alpha \mathrm{v}$ and $\beta 3$ domains of integrin $\alpha \mathrm{v} \beta 3$. For the T4Ac analogue, an interaction with both the subunits is the most probable, with the hydroxylated ring toward $\alpha \mathrm{v}$, while T4 molecule is hypothesized to interact with $\beta 3$ subunit. Other small aromatic ligands interacting with $\alpha \mathrm{v} \beta 3$ integrin (e.g., steroids and resveratrol) can fit into an alternative binding pocket near the RGD binding site, but this site is too small for the THs because of the bulky iodine [48].

Integrin $\alpha v \beta 3$ is highly expressed in activated endothelial cells and newborn vessels, as well as some different cancer cell lines and in primary tissue samples from patients [49]; it also correlates with disease prognosis in various cancer types [50-53].

After the first evidence of MAPK pathway activation by TH, TH-mediated cell proliferation and cancer cell growth stimulation was demonstrated in several cell lines. The effect on glioblastoma C6, F98, and GL261 cells was measured by accumulation of proliferating cell nuclear antigen (PCNA) and radiolabeled thymidine incorporation. This effect was inhibited by the T4 analogue, tetrac, and by an integrin $\alpha v \beta 3$ RGD recognition-site peptide, and it was demonstrated that $\mathrm{T} 3$ and $\mathrm{T} 4$ are equipotent stimulators of PCNA accumulation in glioblastoma cells. However, the in vivo effect on tumor growth is mainly due to T4, since physiological concentrations of T3 are 50-fold lower with respect to T4 [54].

Through molecular modeling and displacement studies, the existence of two sites capable of T3 binding in human glioma U-87 MG cells was suggested, only one of which also binds T4. Both T3 and T4 activate the MAPK-ERK1/2 pathway and cause cell proliferation, whereas only T3 is also capable of enhancing Src kinase and PI3K activities [43]. Furthermore, TH-activated ERK1/2 has been demonstrated to stimulate estrogen receptor- $\alpha(E R \alpha)$, signal transducer and activator of transcription-3 (STAT3), p53, several TR-associated factors, and sodium-proton exchanger $\left(\mathrm{N}^{+} / \mathrm{H}^{+}\right.$antiporter) $[44,45]$ (Figure 3$)$.

By using fluorescently labeled hormones, a selective binding to integrin $\alpha \mathrm{v} \beta 3$-positive ovarian cancer cells (but not integrin-negative cells) was demonstrated and it was also evidenced that $\mathrm{T} 3$ and $\mathrm{T} 4$ nongenomically regulate the transcription of integrin monomers in association with basal integrin levels in the cells [55]. This transcriptional regulation occurs in concert with the clustering of the dimeric $\alpha \mathrm{v} \beta 3$ protein on the cell surface following TH treatment. Similar clustering was shown also in myeloma [56].

The effects of THs when $\alpha \mathrm{v} \beta 3$ is pathologically overexpressed were evaluated [57] and tetrac or its modified forms (tetrac analogues, nanoparticles formulations) were used for the pharmacological blockade of T4 action at $\alpha \mathrm{v} \beta 3$ integrin on different cell types [58-63].

\section{Conclusions}

A multitude of studies have shown that the effects of THs involve both genomic processes and a variety of metabolic pathways. On this basis, the canonical genomic/nongenomic distinction of TH actions must be considered too simplistic and not fully explanatory of all the complex interrelated effects within target cells. On this basis, a better understanding of 
the main events involving THs in the nucleus, where a direct interaction of TH-TR complex with target DNA occurs, and in the cytosol, where TH regulation requires the activation of specific metabolic pathways (in part involving TR isoforms), may help to create a clearer picture of TH dynamics in target cells.

Author Contributions: Conceptualization, L.S. and L.T.; formal analysis, L.S., L.T., C.V., G.I.; writingoriginal draft preparation, L.S., L.T.; review and editing, L.S., L.T., C.V., G.I.; supervision, L.S. All authors have read and agreed to the published version of the manuscript.

Funding: This research received no external funding.

Acknowledgments: The authors are grateful to Sohrab Tanavoli for helpful English editing.

Conflicts of Interest: The authors declare no conflict of interest.

\section{References}

1. Brent, G.A. Mechanisms of thyroid hormone action. J. Clin. Investig. 2012, 122, 3035-3043. [CrossRef]

2. Cheng, S.-Y.; Leonard, J.L.; Davis, P.J. Molecular Aspects of Thyroid Hormone Actions. Endocr. Rev. 2010, 31, 139-170. [CrossRef]

3. Oetting, A.; Yen, P. New insights into thyroid hormone action. Best Pr. Res. Clin. Endocrinol. Metab. 2007, 21, 193-208. [CrossRef]

4. Bernal, J. Thyroid hormone receptors in brain development and function. Nat. Clin. Pr. Endocrinol. Metab. 2007, 3, 249-259. [CrossRef] [PubMed]

5. Taylor, E.; Heyland, A. Evolution of thyroid hormone signaling in animals: Non-genomic and genomic modes of action. Mol. Cell. Endocrinol. 2017, 459, 14-20. [CrossRef]

6. Flamant, F.; Cheng, S.-Y.; Hollenberg, A.N.; Moeller, L.; Samarut, J.; Wondisford, F.E.; Yen, P.; Refetoff, S. Thyroid Hormone Signaling Pathways: Time for a More Precise Nomenclature. Endocrinology 2017, 158, 2052-2057. [CrossRef]

7. Bernal, J.; Guadaño-Ferraz, A.; Morte, B. Thyroid hormone transporters-functions and clinical implications. Nat. Rev. Endocrinol. 2015, 11, 406-417, Erratum in Nat. Rev. Endocrinol. 2015, 9, 506; Erratum in Nat. Rev. Endocrinol. 2015, 12, 690. [CrossRef]

8. Kinne, A.; Schülein, R.; Krause, G. Primary and secondary thyroid hormone transporters. Thyroid. Res. 2011,4 (Suppl. 1), S7. [CrossRef]

9. Friesema, E.C.; Grueters, A.; Biebermann, H.; Krude, H.; von Moers, A.; Reeser, M.; Barrett, T.; Mancilla, E.E.; Svensson, J.; Kester, M.H.; et al. Association between mutations in a thyroid hormone transporter and severe X-linked psychomotor retardation. Lancet 2004, 364, 1435-1437. [CrossRef]

10. Wirth, E.K.; Roth, S.; Blechschmidt, C.; Hölter, S.M.; Becker, L.; Racz, I.; Zimmer, A.; Klopstock, T.; Gailus-Durner, V.; Fuchs, H.; et al. Neuronal 3',3,5-Triiodothyronine (T3) Uptake and Behavioral Phenotype of Mice Deficient in Mct8, the Neuronal T3 Transporter Mutated in Allan-Herndon-Dudley Syndrome. J. Neurosci. 2009, 29, 9439-9449. [CrossRef]

11. Ortiga-Carvalho, T.M.; Sidhaye, A.R.; Wondisford, F.E. Thyroid hormone receptors and resistance to thyroid hormone disorders. Nat. Rev. Endocrinol. 2014, 10, 582-591. [CrossRef] [PubMed]

12. Alkemade, A.; Vuijst, C.L.; Unmehopa, U.A.; Bakker, O.; Vennström, B.; Wiersinga, W.M.; Swaab, D.F.; Fliers, E. Thyroid hormone receptor expression in the human hypothalamus and anterior pituitary. J. Clin. Endocrinol. Metab. 2005, 2, 904-912. [CrossRef]

13. Liu, Y.-Y.; Brent, G.A. Thyroid hormone crosstalk with nuclear receptor signaling in metabolic regulation. Trends Endocrinol. Metab. 2010, 21, 166-173. [CrossRef]

14. Schroeder, A.C.; Privalsky, M.L. Thyroid Hormones, T3 and T4, in the Brain. Front. Endocrinol. 2014, 5, 40. [CrossRef]

15. Zhang, X.-K.; Hoffmann, B.; Tran, P.B.-V.; Graupner, G.; Pfahl, M. Retinoid X receptor is an auxiliary protein for thyroid hormone and retinoic acid receptors. Nature 1992, 355, 441-446. [CrossRef] [PubMed]

16. Hashimoto, K.; Cohen, R.N.; Yamada, M.; Markan, K.; Monden, T.; Satoh, T.; Mori, M.; Wondisford, F.E. Cross-talk between Thyroid Hormone Receptor and Liver X Receptor Regulatory Pathways Is Revealed in a Thyroid Hormone Resistance Mouse Model. J. Biol. Chem. 2006, 281, 295-302. [CrossRef]

17. Liu, Y.Y.; Heymann, R.S.; Moatamed, F.; Schultz, J.J.; Sobel, D.; Brent, G.A. A mutant thyroid hormone receptor alpha antagonizes peroxisome proliferator-activated receptor alpha signaling in vivo and impairs fatty acid oxidation. Endocrinology 2007, 148, 1206-1217. [CrossRef] [PubMed]

18. Aagaard, M.M.; Siersbæk, R.D.; Mandrup, S. Molecular basis for gene-specific transactivation by nuclear receptors. Biochim. Biophys. Acta 2011, 1812, 824-835. [CrossRef]

19. McKenna, N.J.; Xu, J.; Nawaz, Z.; Tsai, S.Y.; Tsai, M.-J.; O’Malley, B.W. Nuclear receptor coactivators: Multiple enzymes, multiple complexes, multiple functionsProceedings of Xth International Congress on Hormonal Steroids, Quebec, Canada, 17-21 June 1998. J. Steroid Biochem. Mol. Biol. 1999, 69, 3-12. [CrossRef]

20. Huang, P.; Chandra, V.; Rastinejad, F. Structural Overview of the Nuclear Receptor Superfamily: Insights into Physiology and Therapeutics. Annu. Rev. Physiol. 2010, 72, 247-272. [CrossRef]

21. Nascimento, A.S.; Dias, S.M.G.; Nunes, F.M.; Aparício, R.; Ambrosio, A.L.; Bleicher, L.; Figueira, A.C.M.; Santos, M.A.M.; Neto, M.D.O.; Fischer, H.; et al. Structural Rearrangements in the Thyroid Hormone Receptor Hinge Domain and Their Putative Role in the Receptor Function. J. Mol. Biol. 2006, 360, 586-598. [CrossRef] [PubMed] 
22. Lazar, M.A. Thyroid hormone receptors: Multiple forms, multiple possibilities. Endocr. Rev. 1993, 2, $184-193$.

23. Yen, P.M. Physiological and Molecular Basis of Thyroid Hormone Action. Physiol. Rev. 2001, 81, 1097-1142. [CrossRef]

24. Anyetei-Anum, C.S.; Roggero, V.R.; Allison, L.A. Thyroid hormone receptor localization in target tissues. J. Endocrinol. 2018, 237, R19-R34. [CrossRef]

25. Plateroti, M.; Gauthier, K.; Domon-Dell, C.; Freund, J.N.; Samarut, J.; Chassande, O. Functional interference between thyroid hormone receptor alpha (TRalpha) and natural truncated TRDeltaalpha isoforms in the control of intestine development. Mol. Cell Biol. 2001, 21, 4761-4772. [CrossRef] [PubMed]

26. Harvey, C.B.; Bassett, J.H.; Maruvada, P.; Yen, P.M.; Williams, G.R. The rat thyroid hormone receptor (TR) Deltabeta3 displays cell-, TR isoform-, and thyroid hormone response element-specific actions. Endocrinology 2007, 148, 1764-1773. [CrossRef]

27. Amma, L.L.; Campos-Barros, A.; Wang, Z.; Vennström, B.; Forrest, D. Distinct Tissue-Specific Roles for Thyroid Hormone Receptors $\beta$ and $\alpha 1$ in Regulation of Type 1 Deiodinase Expression. Mol. Endocrinol. 2001, 15, 467-475. [CrossRef]

28. Zandieh-Doulabi, B.; Dop, E.; Schneiders, M.; Schiphorst, M.P.; Mansen, A.; Vennström, B.; Dijkstra, C.D.; Bakker, O.; Wiersinga, W.M. Zonal expression of the thyroid hormone receptor alpha isoforms in rodent liver. J. Endocrinol. 2003, 179, 379-385. [CrossRef]

29. Zucchi, R. Thyroid Hormone Analogues: An Update. Thyroid 2020, 30, 1099-1105. [CrossRef]

30. Kelly, M.J.; Pietranico-Cole, S.; Larigan, J.D.; Haynes, N.-E.; Reynolds, C.H.; Scott, N.; Vermeulen, J.; Dvorozniak, M.; CondeKnape, K.; Huang, K.-S.; et al. Discovery of 2-[3,5-Dichloro-4-(5-isopropyl-6-oxo-1,6-dihydropyridazin-3-yloxy)phenyl]-3,5-dioxo2,3,4,5-tetrahydro[1,2,4]triazine-6-carbonitrile (MGL-3196), a Highly Selective Thyroid Hormone Receptor $\beta$ Agonist in Clinical Trials for the Treatment of Dyslipidemia. J. Med. Chem. 2014, 57, 3912-3923. [CrossRef] [PubMed]

31. Forrest, D.; Vennström, B. Functions of thyroid hormone receptors in mice. Thyroid 2000, 10, 41-52. [CrossRef]

32. Ma, J.; Goryaynov, A.; Yang, W. Super-resolution 3D tomography of interactions and competition in the nuclear pore complex. Nat. Struct. Mol. Biol. 2016, 23, 239-247. [CrossRef] [PubMed]

33. Roggero, V.R.; Zhang, J.; Parente, L.E.; Doshi, Y.; Dziedzic, R.C.; McGregor, E.L.; Varjabedian, A.D.; Schad, S.E.; Bondzi, C.; Allison, L.A. Nuclear import of the thyroid hormone receptor $\alpha 1$ is mediated by importin 7 , importin $\beta 1$, and adaptor importin «1. Mol. Cell. Endocrinol. 2016, 419, 185-197. [CrossRef]

34. Subramanian, K.S.; Dziedzic, R.C.; Nelson, H.N.; Stern, M.E.; Roggero, V.R.; Bondzi, C.; Allison, L.A. Multiple exportins influence thyroid hormone receptor localization. Mol. Cell. Endocrinol. 2015, 411, 86-96. [CrossRef] [PubMed]

35. Rodríguez, J.A. Interplay between nuclear transport and ubiquitin/SUMO modifications in the regulation of cancer-related proteins. Semin. Cancer Biol. 2014, 27, 11-19. [CrossRef] [PubMed]

36. Sánchez-Pacheco, A.; Martínez-Iglesias, O.; Méndez-Pertuz, M.; Aranda, A. Residues K128, 132, and 134 in the Thyroid Hormone Receptor- $\alpha$ Are Essential for Receptor Acetylation and Activity. Endocrinology 2009, 150, 5143-5152. [CrossRef]

37. Wrutniak-Cabello, C.; Casas, F.; Cabello, G. Thyroid hormone action in mitochondria. J. Mol. Endocrinol. 2001, $26,67-77$. [CrossRef]

38. Carazo, A.; Levin, J.; Casas, F.; Seyer, P.; Grandemange, S.; Busson, M.; Pessemesse, L.; Wrutniak-Cabello, C.; Cabello, G. Protein sequences involved in the mitochondrial import of the 3,5,3'-L-triiodothyronine receptor p43. J. Cell. Physiol. 2012, 227, 3768-3777. [CrossRef]

39. Casas, F.; Rochard, P.; Rodier, A.; Cassar-Malek, I.; Marchal-Victorion, S.; Wiesner, R.J.; Cabello, G.; Wrutniak, C. A variant form of the nuclear triiodothyronine receptor c-ErbAalpha1 plays a direct role in regulation of mitochondrial RNA synthesis. Mol. Cell Biol. 1999, 19, 7913-7924. [CrossRef]

40. Davis, P.J.; Mousa, S.A.; Cody, V.; Tang, H.-Y.; Lin, H.-Y. Small Molecule Hormone or Hormone-Like Ligands of Integrin $\alpha$ V $\beta 3$ : Implications for Cancer Cell Behavior. Horm. Cancer 2013, 4, 335-342. [CrossRef]

41. Bergh, J.J.; Lin, H.Y.; Lansing, L.; Mohamed, S.N.; Davis, F.B.; Mousa, S.; Davis, P.J. Integrin alphaVbeta3 contains a cell surface receptor site for thyroid hormone that is linked to activation of mitogen-activated protein kinase and induction of angiogenesis. Endocrinology 2005, 146, 2864-2871. [CrossRef] [PubMed]

42. Cao, H.J.; Lin, H.Y.; Luidens, M.K.; Davis, F.B.; Davis, P.J. Cytoplasm-to-nucleus shuttling of thyroid hormone receptor-beta1 (Trbeta1) is directed from a plasma membrane integrin receptor by thyroid hormone. Endocr. Res. 2009, 34, 31-42, Erratum in 2009, 34, 155-157. [PubMed]

43. Lin, H.-Y.; Sun, M.; Tang, H.-Y.; Lin, C.; Luidens, M.K.; Mousa, S.A.; Incerpi, S.; Drusano, G.L.; Davis, F.B.; Davis, P.J. 1-Thyroxine vs. 3,5,3'-triiodo-l-thyronine and cell proliferation: Activation of mitogen-activated protein kinase and phosphatidylinositol 3-kinase. Am. J. Physiol. Physiol. 2009, 296, C980-C991. [CrossRef] [PubMed]

44. Chi, H.-C.; Tsai, C.-Y.; Tsai, M.-M.; Yeh, C.-T.; Lin, K.-H. Molecular functions and clinical impact of thyroid hormone-triggered autophagy in liver-related diseases. J. Biomed. Sci. 2019, 26, 1-15. [CrossRef] [PubMed]

45. Incerpi, S.; Luly, P.; De Vito, P.; Farías, R.N. Short-Term Effects of Thyroid Hormones on the Na/H Antiport in L-6 Myoblasts: High Molecular Specificity for 3,3',5-Triiodo- 1 -Thyronine 1. Endocrinology 1999, 140, 683-689. [CrossRef]

46. Barczyk, M.; Carracedo, S.; Gullberg, D. Integrins. Cell Tissue Res. 2010, 339, 269-280. [CrossRef]

47. Xiong, J.P.; Stehle, T.; Zhang, R.; Joachimiak, A.; Frech, M.; Goodman, S.L.; Arnaout, M.A. Crystal structure of the extracellular segment of integrin alpha Vbeta3 in complex with an Arg-Gly-Asp ligand. Science 2002, 296, 151-155. [CrossRef] [PubMed]

48. Cody, V.; Davis, P.J.; Davis, F.B. Molecular modeling of the thyroid hormone interactions with alpha v beta 3 integrin. Steroids 2007, 72, 165-170. [CrossRef]

49. Liu, Z.; Wang, F.; Chen, X. Integrin alpha(v)beta(3)-Targeted Cancer Therapy. Drug Dev. Res. 2008, 69, 329-339. [CrossRef] 
50. Vonlaufen, A.; Wiedle, G.; Borisch, B.; Birrer, S.; Luder, P.; Imhof, B.A. Integrin alpha(v)beta(3) expression in colon carcinoma correlates with survival. Mod. Pathol. 2001, 14, 1126-1132. [CrossRef]

51. Shi, K.; Wang, S.-L.; Shen, B.; Yu, F.-Q.; Weng, D.-F.; Lin, J.-H. Clinicopathological and prognostic values of fibronectin and integrin $\alpha v \beta 3$ expression in primary osteosarcoma. World J. Surg. Oncol. 2019, 17, 1-12. [CrossRef]

52. McCabe, N.P.; De, S.; Vasanji, A.; Brainard, J.; Byzova, T.V. Prostate cancer specific integrin alphavbeta3 modulates bone metastatic growth and tissue remodeling. Oncogene 2007, 26, 6238-6343. [CrossRef] [PubMed]

53. Aksorn, N.; Chanvorachote, P. Integrin as a Molecular Target for Anti-cancer Approaches in Lung Cancer. Anticancer Res. 2019, 39, 541-548. [CrossRef] [PubMed]

54. Davis, F.B.; Tang, H.-Y.; Shih, A.; Keating, T.; Lansing, L.; Hercbergs, A.; Fenstermaker, R.A.; Mousa, A.; Mousa, S.A.; Davis, P.J.; et al. Acting via a Cell Surface Receptor, Thyroid Hormone Is a Growth Factor for Glioma Cells. Cancer Res. 2006, 66, 7270-7275. [CrossRef]

55. Shinderman-Maman, E.; Cohen, K.J.; Weingarten, C.; Nabriski, D.; Twito, O.; Baraf, L.; Hercbergs, A.; Davis, P.J.; Werner, H.; Ellis, M.J.; et al. The thyroid hormone- $\alpha \mathrm{v} \beta 3$ integrin axis in ovarian cancer: Regulation of gene transcription and MAPK-dependent proliferation. Oncogene 2016, 35, 1977-1987. [CrossRef]

56. Cohen, K.; Ellis, M.; Khoury, S.; Davis, P.J.; Hercbergs, A.; Ashur-Fabian, O. Thyroid Hormone Is a MAPK-Dependent Growth Factor for Human Myeloma Cells Acting via $\alpha v \beta 3$ Integrin. Mol. Cancer Res. 2011, 9, 1385-1394. [CrossRef]

57. Hercbergs, A.; Davis, P.J.; Lin, H.-Y.; Keating, K.A.; Mousa, S.A. Thyroid Hormone Replacement Therapy in Patients with Various Types of Cancer. Intechopen.com. 2019. Available online: https://www.intechopen.com/chapters/67201 (accessed on 15 September 2021).

58. Lin, H.-Y.; Landersdorfer, C.B.; London, D.; Meng, R.; Lim, C.-U.; Lin, C.; Lin, S.; Tang, H.-Y.; Brown, D.; Van Scoy, B.; et al. Pharmacodynamic Modeling of Anti-Cancer Activity of Tetraiodothyroacetic Acid in a Perfused Cell Culture System. PLoS Comput. Biol. 2011, 7, e1001073. [CrossRef] [PubMed]

59. Lin, H.-Y.; Chin, Y.-T.; Nana, A.W.; Shih, Y.-J.; Lai, H.-Y.; Tang, H.-Y.; Leinung, M.; Mousa, S.; Davis, P.J. Actions of 1-thyroxine and Nano-diamino-tetrac (Nanotetrac) on PD-L1 in cancer cells. Steroids 2016, 114, 59-67. [CrossRef]

60. Sudha, T.; Bharali, D.J.; Sell, S.; Darwish, N.H.E.; Davis, P.J.; Mousa, S.A. Nanoparticulate Tetrac Inhibits Growth and Vascularity of Glioblastoma Xenografts. Horm. Cancer 2017, 8, 157-165. [CrossRef]

61. Mousa, S.A.; Yalcin, M.; Bharali, D.J.; Meng, R.; Tang, H.-Y.; Lin, H.-Y.; Davis, F.B.; Davis, P.J. Tetraiodothyroacetic acid and its nanoformulation inhibit thyroid hormone stimulation of non-small cell lung cancer cells in vitro and its growth in xenografts. Lung Cancer 2012, 76, 39-45. [CrossRef]

62. Glinskii, A.B.; Glinsky, G.V.; Lin, H.-Y.; Tang, H.-Y.; Sun, M.; Davis, F.B.; Luidens, M.K.; Mousa, S.; Hercbergs, A.H.; Davis, P.J. Modification of survival pathway gene expression in human breast cancer cells by tetraiodothyroacetic acid (tetrac). Cell Cycle 2009, 8, 3562-3570. [CrossRef] [PubMed]

63. Hercbergs, A.; Johnson, R.E.; Ashur-Fabian, O.; Garfield, D.H.; Davis, P.J. Medically Induced Euthyroid Hypothyroxinemia May Extend Survival in Compassionate Need Cancer Patients: An Observational Study. Oncologist 2015, 20, 72-76. [CrossRef] [PubMed] 